\title{
In Vitro Digestibility of Fiber Fraction of Aerobically Deteriorated Silage
}

\author{
Sakae MatsuoKa and Hiroshi FuJITA \\ Department of Animal Production and Agricultural \\ Economics, Obihiro University of Agriculture \\ and Veterinary Medicine, Obihiro-shi 080
}

(Received April 13, 1993)

Key words : silage, aerobic deterioration, fiber fraction, in vitro digestibility

The influence of aerobic deterioration on the chemical composition and fermentation quality of silage is well known", but limited information is available concerning its influence on silage digestibility. The digestibilities of crude protein and nitrogen-free extracts (NFE) appear to be consistently decreased by aerobic deterioration ${ }^{5,7,8)}$. However, the influence of aerobic deterioration on the digestibility of fiber fractions such as crude fiber, neutraldetergent fiber (NDF) and acid-detergent fiber (ADF) is rather inconsistent. In our previous digestion trials ${ }^{7,8)}$ with wether sheep, it was shown that the digestibilities of fiber fractions of aerobically deteriorated silages were higher than those of undeteriorated control silages. Similar enhancement of fiber digestion by aerobic deterioration was also noted by DEoKA et $a l .{ }^{4}$.

This paper presents results from an in vitro digestion trial using as a substrate, the silages used in a previous in vivo trial ${ }^{8)}$ to discuss the nature of this enhancement.

\section{Materials and Methods}

Preparation of substrate: High- and lowmoisture silages with and without aerobic exposure treatment used in a previous study ${ }^{8)}$ were used as a substrate after being freezedried and ground to pass through a $1-\mathrm{mm}$ screen.

A broad outline of the aerobic exposure treatment is as follows : after removal from silos, each of the high- and low-moisture silages which contained about 80 and $55 \%$ moisture, respectively, being made from the same grass material, was divided into two parts. Each first part was stacked in the open air for 7 days, then immediately stored in a refrigerator and used as undeteriorated control silage. More details have been reported previously ${ }^{8)}$.

Washed silages were also prepared as a substrate to remove the effects of differences in fermentation quality between deteriorated and control silages.

The silages were treated as follows: about $30 \mathrm{~g}$ of above ground silages (unwashed silages) was put into $1 l$ beaker and then about $600 \mathrm{ml}$ of distilled water was added. The beaker was kept in an icebox overnight, and the content was stirred occasionally. After adjusting the $\mathrm{pH}$ content to 6.8 with $\mathrm{N}-\mathrm{Na}_{2} \mathrm{CO}_{3}$ or $\mathrm{N}-\mathrm{HCl}$, the beaker was put in an icebox again for

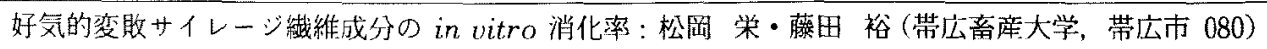

Anim. Sci. Technol. (Jpn.) 64 (10): 1010-1012 1010 
several hours. The content was strained through two layers of surgical gauze and then the strained fluid was centrifuged at $18,000 \times \mathrm{g}$ for $20 \mathrm{~min}$. After mixing the precipitate with the strained residue, the whole residue was freeze-dried to be used as washed silage.

In vitro digestibility trial: The in vitro digestibility of dry matter was determined by the two-stage method of TILLEY and TERRY ${ }^{11}$, in which the ground substrates were incubated with buffer solution and rumen liquor strained through a filter cloth for 48 hours in the first stage. Those of NDF and ADF were determined by a modified method ${ }^{3)}$ in which the second stage in the two-stage method is substituted with a neutral- or acid-detergent extraction. Quintuplicate samples of each ground silage were used for this determination.

Analyses: The chemical composition of the silages were determined by the methods given in a previous report ${ }^{7)}$.

\section{Results and discussion}

A precious in vivo trial ${ }^{8)}$ showed that dry matter digestibility of deteriorated silages was lower than that of control silages, even when the fiber digestibility was higher. In this study, similar results were obtained (Table 1). This is probably because the depression in crude protein and NFE digestibilities by aerobic deterioration overcomes the enhancement of fiber digestibility. It is considered that the depression in crude protein digestibility is primarily due to denaturation of protein ${ }^{5)}$ and the loss of soluble protein ${ }^{8}$ by aerobic deterioration, and that in NFE is due to the loss of readily digestible carbohydrates such as WSC and organic acids such as lactic acid and VFA ${ }^{8}$.

The in vitro trial (Table 1) showed that digestibilities of NDF and ADF were significantly higher for the deteriorated silages than for the control silages. However, the differences were considerably smaller, than those in a previous in vivo trial ${ }^{8}$, in which for highmoisture silage, the digestibilities of NDF for deteriorated and control silages were 72.8 and $65.5 \%, \mathrm{ADF} 65.0$ and $62.9 \%$; and for lowmoisture silage, $\mathrm{NDF} 78.2$ and $67.3 \%, \mathrm{ADF}$ 71.9 and $64.9 \%$, respectively. In a previous report $^{8}$, it was pointed out that the following factors might contribute to the higher fiber digestibility of the deteriorated silage : (1) it contained more isoacids which stimulated fiber digestion in the rumen ${ }^{13}$; (2) it contained less

Table 1. Chemical composition and in vitro digestibility of fiber fraction of aerobically deteriorated silage

\begin{tabular}{|c|c|c|c|c|c|c|c|c|c|c|c|c|}
\hline & \multicolumn{6}{|c|}{ High-moisture silage } & \multicolumn{6}{|c|}{ Low-moisture silage } \\
\hline & \multicolumn{2}{|c|}{ Unwashed } & \multirow{2}{*}{$\mathrm{SE}$} & \multicolumn{2}{|c|}{ Washed } & \multirow{2}{*}{$\mathrm{SE}$} & \multicolumn{2}{|c|}{ Unwashed } & \multirow{2}{*}{$\mathrm{SE}$} & \multicolumn{2}{|c|}{ Washed } & \multirow{2}{*}{$\mathrm{SE}$} \\
\hline & $\mathrm{C}$ & $\mathrm{D}$ & & $\mathrm{C}$ & $\mathrm{D}$ & & $\mathrm{C}$ & $\mathrm{D}$ & & $\mathrm{C}$ & $\mathrm{D}$ & \\
\hline \multicolumn{13}{|c|}{ Chemical composition ( $\%$ on dry matter basis) } \\
\hline Dry matter & 94.4 & 93.2 & & 92.5 & 92.3 & & 90.6 & 90.0 & & 91.9 & 91.7 & \\
\hline Crude protein & 14. 1 & 12.6 & & 9.3 & 10.9 & & 14.5 & 13.8 & & 10.1 & 10.9 & \\
\hline WSC & 5.4 & 4.9 & & 3.2 & 2.5 & & 8.4 & 6.6 & & 3.2 & 2.4 & \\
\hline NDF & 56.2 & 67.7 & & 75.5 & 79.0 & & 58.4 & 66.2 & & 74.2 & 75.8 & \\
\hline ADF & 35.7 & 47.5 & & 49.3 & 55.8 & & 38.3 & 48.3 & & 51.5 & 55.3 & \\
\hline \multicolumn{13}{|l|}{ Digestibility (\%) } \\
\hline Dry matter & 65.5 & $61.3^{* *}$ & \pm 0.46 & 51.5 & 49. $4^{* * *}$ & \pm 0.57 & 64.2 & $61.2^{* *}$ & \pm 0.40 & 56.2 & $57.7^{* *}$ & \pm 0.26 \\
\hline NDF & 59.9 & $62.9^{*}$ & \pm 0.94 & 56.6 & $58.3^{*}$ & \pm 0.52 & 61.2 & $64.9^{* *}$ & \pm 0.83 & 58.2 & $60.3^{* *}$ & \pm 0.63 \\
\hline$A D F$ & 61.9 & $65.5^{* *}$ & \pm 0.87 & 56.0 & $58.5^{* *}$ & \pm 0.49 & 64.5 & $67.6^{* *}$ & \pm 0.73 & 65.0 & $67.4^{* *}$ & \pm 0.59 \\
\hline
\end{tabular}

C: Control (undeteriorated) silage $\mathrm{D}$ : Deteriorated silage SE : Standard error

*, ** : Significantly different $(\mathrm{P}<0.05, \mathrm{P}<0.01$, respectively) from the value for control silage. 
water-soluble carbohydrates (WSC) which lowered fiber digestibility above a certain level ${ }^{2)}$; (3) its $\mathrm{pH}$ was higher, resulting in a higher $\mathrm{pH}$ value in the rumen, whose condition was suitable for the activity of fiber digesting microorganisms ${ }^{10)}$; and (4) its fiber fraction changed to become more easily digested. (1), (2) and (3) derived from the changes in fermentation quality caused by aerobic deterioration, and are considered to affect fiber digestion less in vitro than in vivo, because the concentration of substrate in in vitro digestibility trials is only about $1 \%, w / v$, much less than in the rumen, where it is $8-18 \%, \mathrm{w} / \mathrm{v}^{6}$. This is reflected in the result that for NDF and ADF digestilities, the differences between deteriorated and control silages were smaller in vitro than in vivo.

In this study, silage samples were washed with water to remove as much as possible the effects of differences in fermentation quality, including $\mathrm{pH}$ value, lactic acid, VFA, isoacids, WSC contents and so on. As a result, the NDF and ADF digestibilities of washed silages were still significantly higher for the deteriorated silages than for the control silages, although the differences were somewhat small as compared to those of the unwashed silages. This difference is considered to indicate increased fiber digestibility caused by the change in the fiber fraction itself.

As mentioned above, the differences between NDF and ADF in vitro digestibilities between the deteriorated and control silages were apparently smaller than those in vivo ${ }^{8)}$, and the differences after washing treatment with water were still significant. From these results, it is considered that the higher in vivo digestibility of fiber in the deteriorated silage is mainly due to the changes in fermentation quality and due in small part to changes the fiber itself caused by aerobic deterioration.

\section{Reference}

1) Andries, J.I., F.X. Buysse, D.L. De
Brabander and B.G. Cottyn, Isoacids in ruminant nutrition: Their role in ruminal and intermediary metabolism and possible influences on performances - A review. Anim. Feed Sci. and Technol., 18: 169-180. 1987.

2) BARnett, A.J.G. and R.L.Reid, Reactions in the rumen. 94-99. Edward Arnold (Publishers) Ltd. London. 1961.

3) Daughtry, C.S.T., D.A. Holt and V.L. LeChTENBerg, Concentration, composition, and in vitro disappearance of hemicellulose in tall fescue and orchardgrass. Agron. J., 70 : 550-554. 1978.

4) Deoka, K., T. Bando and M. Okamoto, Effect of aerobic deterioration of corn silage on rumen fermentation, ruminating behavior and digestibility by sheep. Bull. Shintoku Anim. Husb. Exp. Stn., 12: 1925. 1982.

5) Fujita, H., S. Matsuoka, J. Takahashi, A. Fukuzawa and K. TAKase, Effect of aerobic deterioration on the nutritive value of grass silage. Jpn. J. Zootech. Sci., 51 : 511-518. 1980.

6) Hungate, R. E., The rumen and its microbes. 253-255. Academic Press. New York. 1966.

7) Matsuoka, S., E. Yasuda, B. Yokoyama, $K$. TAKAOKA, K. YAMAgUCH and $\mathrm{H}$. Fujita, Decline in nutritive value and loss of nutrients of grass silage by aerobic deterioration. Anim. Sci. Technol. (Jpn.), 62: 552-557. 1991.

8) Matsuoka, S., S. Yonezawa, H. Ishitobi, K. Osanai and H. FujtTa, Effects of moisture content on the decline in nutritive value and the loss of nutrients of grass silage by aerobic deterioration. Anim. Sci Technol. (Jpn.), 62 : 558-564. 1991.

9) McDonald, P., A.R. Henderson and S.J.E. Heron, The biochemistry of silage. 2nd ed. 158-163. Chalcombe Publications. Aberystwyth. 1991.

10) Stewart, C.S., Factors affecting the cellulolytic activity of rumen contents. Appl. Environ. Microbiol. 33 : 497-502. 1977.

11) Tilley, J.M.A. and R.A. TerRy, A twostage technique for the in vitro digestion of forage crops. J. Brit. Grassl. Soc., 18: 104-111. 1963. 